\title{
THE IMPACT OF OFFSHORING ON FIRM’s EXPORTS
}

\author{
EL IMPACTO DEL OFFSHORING EN LAS EXPORTACIONES DE LAS EMPRESAS
}

Carmen Martínez-Mora

Universidad De Alicante

cmmora@ua.es

Fernando Merino de Lucas

Universidad de Murcia

fmerino@um.es

Recibido: diciembre de 2018; aceptado: noviembre de 2019

\section{ABSTRACT}

Offshoring is a strategy that has been widely used as a mean to reduce costs, increase firms' productivity and flexibility. Consequently, it is aimed to improve the competitive situation of the firm in its markets. But beyond this effect, we depart from international business literature, the resourcebased view and transaction cost economics to argue that offshore helps firms to export, not only because it increases its productivity and flexibility but because it provides some knowledge and expertise to develop themselves in international markets. Departing from this framework, we present an empirical study over Spanish manufacturers that confirms that firms that offshore export more, and that this extra effect is larger in small firms than in large ones.

Keywords: outsourcing; offshoring; exports; inward-outward connections; multinational enterprises. 
RESUMEN

El offshoring es una estrategia que se utiliza ampliamente para reducir costes, aumentar la productividad y flexibilidad de las empresas. En consecuencia, busca mejorar la posición competitiva de la empresa en sus mercados. Partiendo de la literatura de la economía internacional, la visiōn de la empresa basada en los recursos y la teoría de los costes de transacción, se plantea que el offshoring ayuda a las empresas a exportar, no sólo por el aumento en su productividad y flexibilidad sino por proporcionar conocimiento y experiencia sobre los mercados extranjeros. Desde este marco se presenta un estudio empírico sobre empresas manufactureras españolas que confirma que las empresas que hacen offshoring exportan más y que este efecto es mayor en las empresas pequeñas que en las grandes.

Palabras clave: externalizaciōn; offshoring; exportaciones; empresas multinacionales.

Clasificación JEL: F23, F12, M16 


\section{INTRODUCTION}

Existing empirical evidence reveals that offshoring processes have been increasingly expanding throughout the world since the 1990s. One of the consequences of this expansion has been the huge growth in the imports of inputs by the offshoring firms (Feenstra, 1998; Feenstra and Hanson, 1996; Campa and Golberg, 1997; Hummels et al., 2001). The most recent theoretical models of international trade (Olsen, 2006; Blinder, 2006; Grossman and Rossi-Hansberg, 2006; Helpman, 2011) reveal that the new patterns of trade, based on the international fragmentation of production and the international specialisation on the most efficient phases of the value chain rather than on the final output, give rise to gains in efficiency and welfare and, therefore, boost economic growth in the long term. However, there is also empirical evidence, based on both industry data (Amiti and Wei 2009; Winkler 2010; Michel and Rycx 2012; Agnese 2012; Cadarso, 2008, Bogliacino et al. 2018) and business data (Görg and Hanley 2005; Hijzen et al. 2015; Crinō, R. 2010; Liu and Trefler 2008; Martins and Opromolla 2009; Amiti and Davis 2011; Krishna 2011; Hummels et al., 2014) of the existence of short-term negative effects on employment and wages.

Literature based on the Resource Based View of the firm, International Business as well as Transaction Costs Economics remark three elements that might push firm's competitiveness thanks to offshoring. Firstly, we find the cost advantage that offshoring supposes at the extent that offshoring is explained for searching lower costs placements, more flexible legislation, etc. Second, firms become more flexible since they do not need to tie up resources in those stages of the value chain where the firm has no competitive advantage; third, offshoring allows the firm to access to cutting-edge technologies and the most efficient production processes for those intermediate inputs that it incorporates to its final output. The empirical evidence of positive effects is largely based on studies using business data, following Melitz (2003) which focuses on the impact on productivity. In all cases, positive effects on the productivity of the firms that carry out offshoring are obtained (Ethier, 1982; Markusen, 1989; Grossman and Helpman, 1991; Fariñas and Martîn, 2009) although more research seems necessary to capture different effects or/and to evaluate properly all the consequences of offshoring (Lahiri, 2016).

Melitz's model, which introduces the heterogeneity of firms as a distinctive element, concludes that only those firms with the highest productivity levels 
will export. Therefore, it can be deduced that if offshoring processes reinforce the productivity of firms, they should also lead to an increase in exports, either because new firms obtain the minimum levels of productivity necessary to be able to export (extensive margin) or because, due to their increased productivity and efficiency the exporting firms also increase their exports (intensive margin). The empirical evidence regarding the impact of offshoring on exports is a growing research area (Bertrand, 2011, Bas and Strauss-Kahn, 2014; Lo Turco and Maggioni, 2013; Aresti et al., 2013 and Danninger and Fred, 2008).

The aim of this paper is to contribute to provide evidence on the relation between offshoring and exporting. This will increase the knowledge on the effects of offshoring on firms. Beyond the interest for the management literature, these results provide a valuable evidence for international trade policies. Currently, tariffs and other protectionist policies are becoming increasingly popular in some countries. Then a better knowledge of the effects of offshoring, this is sourcing from abroad, in exports will help to evaluate better the consequences of such policies, since making imports more difficult, or costly, will affect exports too. Furthermore, if it can be confirmed that offshoring has a positive effect on exports, this would constitute an additional argument for the case that offshoring is beneficial for the economy and growth and one which could compensate the possible negative effects derived from short-term job losses.

The analysis focuses on the exporting behaviour of Spanish manufacturing firms. A firm-level study has been carried out based on the information provided by the Survey on Business Strategies (Encuesta de Estrategias Empresariales, ESEE) conducted by Spain's Ministry of Industry. The study analyses which firms import intermediate inputs and examines whether the offshoring firms are the largest exporters or not (extensive margin) and whether they export more than the rest (intensive margin). With it, we contribute to provide additional research on the needed directions of future research (specific effects of international outsourcing, alternative performance indicators than those that capture financial results or productivity measures) that some scholars have identified (Lahiri, 2016).

The paper is structured as follows. After the introduction section, the theoretical bases and the previous empirical evidence are described. Then, the descriptive analysis of Spanish manufactured goods and the empirical analysis are carried out. Finally, the results are presented and the conclusions are drawn with suggestions for future lines of research.

\section{TheOrEticAl BASES AND PREVIOUS EMPIRICAL EVIDENCE}

Offshoring, the substitution of production at home for production abroad as part of the production process, has increased notoriously along the last decades in almost all advanced economies although in the most recent years 
some returning cases are happening (Tate, 2014). Firms seek for lower costs using production in other places (may be because some costs are lower, specially labour, legislation is less restrictive, there are specialized firms that add large quantities and exploit scale economies, ...) but also for the access to the most efficient specialized producers or just the flexibility that supposes to adjust more easily the amount of intermediate inputs according their final demand. Whatever the main purpose for offshoring is, it aims to improve the competitive position of the firm (because it uses cheaper intermediate inputs, because it can concentrate its resources in those core activities where the firm has a competitive advantage, or any other reason).

One of the consequences of being more competitive, is that firms can succeed in international markets. As models like Melitz (2003) and Grossman and Helpman (1991) show, more efficient firms are the ones that have the opportunity to enter successfully in international markets. So, at the extent that offshoring is increasing the efficiency level that firms show to compete in their markets, it will become a strategy that increases the likelihood of exporting. Additionally, offshoring provides knowledge of the foreign country that can be valuable to export (see Choquette, 2019, Hernández and Nieto, 2016). In this line, an interesting literature has focused on the relationship between offshoring and exporting.

The first theoretical reference that analyses the relationship between offshoring and exports within the framework of the heterogeneity of firms can be found in the papers by Kleinert and Zorell (2012) and Kashara and Lapham (2013). Both of them are based on the empirical results obtained by Muûls and Pisu (2009). In this study an exhaustive descriptive analysis is carried out together with an econometric analysis of the characteristics of the exporting and importing firms of Belgium, using firm-level data for the years between 1996 and 2004. Both analyses reveal that the firms that both export and import are those that have higher levels of productivity, followed by those who export or import and those with the lowest levels of productivity are those that only operate in their domestic markets. Therefore, the authors conclude that both imports and exports are subject to fixed costs and that in both cases a self-selection process occurs which only allows the most productive firms to take part in international trade.

Kleinert and Zorell (2012) and Kasahara and Lapham (2013) present general equilibrium models with heterogenous firms based on Melitz (2003) and they show how offshoring promotes exports and therefore intensify world trade. This result is based, in Kleinert and Zorrel (2012) model, on the reduction of the input costs generated by the offshoring processes, as those firms that practice it, as they relocate their production processes through intra-industry trade to countries with lower costs. That leads to firms that previously found unprofitable to export, to reduce their costs and to start to sell abroad (extensive margin) or to those firms that were exporting to become more competitive due to the cost reduction (intensive margin). In Kasahara and Lapham (2013) model an additional assumption to the cost 
reduction that offshoring supposes is included: the production function exhibits increasing returns with the variety of goods produced and imported. In equilibrium, it means that firms that export and import inputs are those with the highest levels of productivity and additional increases in productivity are gained through the import of additional inputs to those acquired in the domestic market. It supposes a push for exports. Both models introduce the assumption of fixed costs, as well as the variable costs, for the offshoring processes, in addition to those that are considered in the Melitz model for exports, which implies that only the most productive firms will export and practice offshoring.

Although there are many empirical studies that demonstrate the positive impact of offshoring on productivity (see the meta-analysis by Awe et al., 2018, that concludes that offshoring enhances firm performance), the effect on exports has received much less attention. The available studies focus on a variety of countries and in all cases from the perspective of the Melitz (2003) model and the afore-mentioned extensions of it by Kleinert and Zorell (2012) and Kashara and Lapham (2013), in other words, based on firm-level data and the heterogeneity hypothesis.

The most remarkable empirical papers are those ones by Bas and StraussKahn (2014), Lo Turco and Maggioni (2013) and Aresti, Castellani and Franco (2013) and Bertrand (2011), summarized in Table 1. The first and last ones analyzes French firms, the second one Italian ones and the third one some East European \& Central Asian cases. In the two first references three hypotheses are tested for France and Italy: the first is related to the variety and complementarity, whereby it is assumed that when a wider variety of inputs is imported the complementarity between the imported inputs and domestic inputs improves, leading to improvements in productivity which allows exports to increase. The second hypothesis refers to the transfer of technology incorporated in the imported inputs, which is also assumed to improve productivity and therefore exports. Finally, the third hypothesis refers to the price effect which is obtained through importing inputs with a lower cost than domestic inputs giving rise to a price-based competitiveness effect, which, in turn, should boost exports. For France, a positive and significant effect is obtained for the first two hypotheses in the case where the inputs are imported from developed countries. In other words, a strong positive relationship is found between the number of imported inputs and the varieties exported. However, a significant effect is not obtained for the third hypothesis referring to the price effect. For Italy, results reveal that inputs coming from countries with low wage costs have a positive and significant impact on exports and the import of inputs from advanced economies has a negative and insignificant effect on exports. The explanation given by the authors for this result is based on the characteristics of the exporting pattern of the Italian manufacturing firms, focused on traditional products with a low technological content and with a competitiveness based fundamentally on price. For this reason, the positive impact of offshoring on exports is derived 
from the savings in costs and not from technology. They conclude that the dominant competitiveness strategies of the Italian manufacturing firms are based mainly on the saving of costs through the use of inputs from low-income countries, pressured by the competition of these types of products from emerging economies.

Aresti, Castellani and Franco (2013) analyse the relationship between exports and imports with a sample of 1,085 firms for the years between 2000 and 2008 of 27 countries from Eastern Europe and Central Asia. In this case, they study both the effect of exports on the import of inputs and that of imports on exports, based on the empirical evidence that reveals that a large part of the internationalised firms implement both strategies: exporting and importing. They ask whether the two are related, due to the self-selection process derived from the sunk costs common to both strategies or because one facilitates the other. They only obtain a positive impact in the last case, that is, the effect of offshoring on exports, but not in the inverse case. The positive effect of offshoring on exports is generated by the increase in the productivity of firms and the innovation of the product, that is, through technology. In a closer perspective, Bertrand (2011) analyzes this effect on French firm, departing from the resource based view of the firm. In his analysis, he concludes that offshoring may generate new resources and market knowledge for firms, which leads to a more intense export behaviour if the firm has developed the necessary absorptive capacity. The effect becomes more important in those markets where the firm is supplying throughout its offshoring strategy.

Finally, we should refer to the study by Danninger and Fred (2008), which was conducted before the above-mentioned studies and although it does not use the same methodology, it constitutes the beginning of the empirical analysis of the effect of offshoring on exports. In this study, the determinants of the growth of German exports from the year 2000 are analysed using export data from the period 1993 to 2005. Among other factors, such as the improvement in cost-based competitiveness, the increase in relations with trading partners and the increase in the demand for capital goods, the study also estimates the impact of the regionalisation of the production of goods, that is, of offshoring. The results reveal that the offshoring factor, together with the increase in trading relations with countries with greater economic growth explain seventy per cent of the export growth from the year 2000. The effect of the other two factors was not found to be significant. 
TABLE 1. EMPIRICAL EVIDENCE ON OFFSHORING-EXPORT

\begin{tabular}{|c|c|c|c|}
\hline Authors & Country & Period & $\begin{array}{c}\text { Results: } \\
\text { Effect of offshoring on exports }\end{array}$ \\
\hline \multicolumn{4}{|l|}{ Firm-level data } \\
\hline $\begin{array}{l}\text { Bas and Strauss-Kahn } \\
(2014)\end{array}$ & France & $1995-2005$ & $\begin{array}{l}\text { Positive and significant impact due } \\
\text { to the complementarity resulting } \\
\text { from increasing the variety of inputs } \\
\text { and technology. Non-significant } \\
\text { impact for the price effect }\end{array}$ \\
\hline $\begin{array}{l}\text { Lo Turco and Maggioni } \\
\text { (2013) }\end{array}$ & Italy & 2000-2004 & Positive impact of the price effect \\
\hline $\begin{array}{l}\text { Aresti, Castellani and } \\
\text { Franco (2013) }\end{array}$ & $\begin{array}{l}27 \text { countries of } \\
\text { Eastern Europe and } \\
\text { Central Asia }\end{array}$ & $2000-2008$ & $\begin{array}{l}\text { Positive impact due to the produc- } \\
\text { tivity and innovation of the product }\end{array}$ \\
\hline Bertrand (2011) & France & 1999 & $\begin{array}{l}\text { Positive impact, variable across } \\
\text { firms and countries which is attrib- } \\
\text { uted to the absorptive capabilities } \\
\text { of firms }\end{array}$ \\
\hline \multicolumn{4}{|l|}{ Sector-level data } \\
\hline $\begin{array}{l}\text { Danninger and Fred } \\
(2008)\end{array}$ & Germany & 1993-2005 & Positive and significant impact \\
\hline
\end{tabular}

Source: Author's own elaboration.

\section{Descriptive analysis of the data for Spain}

This study uses the firm-level data for the year 2013 compiled in the Survey on Business Strategies (Encuesta de Estrategias Empresariales, ESEE) carried out by the SEPI Foundation of Spain's Ministry of Industry. This survey contains a representative sample of the Spanish manufacturing firms with ten or more employees and includes, almost exhaustively, the large firms with more than 200 employees and a random and stratified selection of the rest, with a total of around 2,000 firms.

In the analysis, three types of firms are distinguished depending on their size. The group of small firms includes those ones with less than 50 workers. The group of medium size firms refers to those with between 50 and 250 workers and the large firm's group includes those ones with more than 250 workers.

As is the case in other studies, the offshoring strategy has been identified with the import of intermediate goods by each firm. The ESEE includes this question to firms, establishing whether imports are made to firms in the same shareholders' group or to third parties which allows for an analysis of both situations. Moreover, the case when offshoring is not carried out can also be studied.

Table 2 shows the extensive margin (percentage of exporters), and intensive margin (export propensity, this is the exports/sales ratio), in accordance with the international sourcing strategies carried out by the firms. 
TABLE 2. EXPORTING ACTIVITY ACCORDING FIRMS' OFFSHORING STRATEGY

\begin{tabular}{|l|c|c|c|c|c|c|}
\hline & \multicolumn{5}{|c|}{ Offshoring strategy } \\
\hline & \multicolumn{2}{|c|}{ Do not offshore } & \multicolumn{2}{|c|}{$\begin{array}{c}\text { To the group } \\
\text { (captive offshoring) }\end{array}$} & \multicolumn{2}{c|}{$\begin{array}{c}\text { To third parties } \\
\text { (intern. outsourcing) }\end{array}$} \\
\hline & $\begin{array}{c}\% \\
\text { exporters }\end{array}$ & $\begin{array}{c}\text { Exports/ } \\
\text { sales (\%) }\end{array}$ & $\begin{array}{c}\% \\
\text { exporters }\end{array}$ & $\begin{array}{c}\text { Exports/ } \\
\text { sales (\%) }\end{array}$ & $\begin{array}{c}\% \\
\text { exporters }\end{array}$ & $\begin{array}{c}\text { Exports/ } \\
\text { sales (\%) }\end{array}$ \\
\hline Total firms & 67.56 & 22 & 89.12 & 44 & 90.08 & 35 \\
\hline $\begin{array}{l}\text { Small firms (<50 } \\
\text { workers) }\end{array}$ & 47.53 & 10 & 75.63 & 21 & 75.51 & 21 \\
\hline $\begin{array}{l}\text { Medium-sized firms } \\
\text { (50-250) }\end{array}$ & 86.08 & 33 & 93.00 & 51 & 94.24 & 39 \\
\hline Large firms (>250) & 90.93 & 35 & 95.91 & 40 & 95.80 & 40 \\
\hline
\end{tabular}

Source: Authors' own elaboration based on the ESEE-2013.

Of the total firms that do not practice offshoring, 67.6 per cent are exporters that export approximately 22 per cent of their sales. As it is well known, this percentage is much lower for small firms ( 47.5 per cent) and is higher for the medium-sized firms (86.08 per cent) and much higher for large firms (90.9 per cent). The same occurs with the export intensity.

Among firms that practice offshoring from the same group, the percentage of exporters is substantially high. For the total of the firms, this percentage is 89.12 per cent. As in the previous case, this percentage is lower for the small firms (75.63 per cent). However, this percentage is higher in the case of those small firms that offshore and even higher for medium-sized firms (93 per cent) and large firms (95.91 per cent). Similarly, the frequency of exporters is higher in this case for all of the firm groups, but particularly for the small and medium-sized firms. It is also higher for the large firms but only slightly.

The result is the same for firms that carry out offshoring to third parties not linked the firm. Of these firms, more than 90 per cent are exporting firms with average exports of 35 per cent of the value of their sales. As observed in the other groups, the percentage increases with the size of the firm.

The result for the descriptive data presented points to a positive relation between offshoring and exporting, in accordance with the existing evidence for other countries. In other words, the percentage of exporting firms (extensive margin) is higher among those firms that practice offshoring. Nevertheless, it should be noted that the increase in the percentage of exporters among those that practice offshoring is different depending on the size of the firms considered. Although in all cases there is an increase in the number of firms that export when offshoring is implemented, the most notable increases can be found in the medium-sized firms and most of all in the small firms. The large firms also experience increases but to a much lesser extent. The explanation for this result may lay in the fact that the large firms are, on the whole, exporters, irrespectively of whether they offshore or not, as they have 
the necessary advantages to implement internationalisation strategies and assume the fixed and variable costs associated with exporting through other means (a higher capacity of resources that enables them to exploit economies of scale, productivity, innovative activity, etc.) which corresponds with the results of the studies on exports referring to the Spanish economy (Myro, 2013; Myro, 2015). On the other hand, the offshoring effect is more notable in the case of medium-sized firms and considerably greater in the case of small firms. The explanation may reside in the fact that these firms encounter more difficulties when they first enter the exporting process, precisely due to the lack of the capacities enjoyed by the large firms (resources, experience, productivity...) or the necessary knowledge of foreign markets. Therefore, of these groups of firms, those that import intermediate goods are those with the highest exports. Given that both exporting and importing imply sunk costs, the firms that are able to assume them in importing are, on the whole, those that can also export, in accordance with the results obtained by Gandoy et al., (2014).

On the other hand, the firms that offshore also exhibit a higher export propensity than those that do not (intensive margin). Furthermore, the percentage is higher when the offshoring is carried out within the same group than when it is conducted with third parties. In this case, the result is also more significant for the groups of medium-sized firms and most of all the small firms than the large firms.

The data source used also classifies the firms by their sector of activity. Therefore, we have calculated the percentages of exporters according to whether they offshore or not for the different sectors in order to determine those sectors that most correspond to the hypothesis of the study. The results are presented in Table 3.

Of the firms that practice offshoring, in all sectors of activity the percentage of exporting firms is equal to or higher than 60 per cent. Only in beverages and timber industry sectors are these percentages 60 per cent and 60.9 per cent respectively. In food products, leather and footwear, nonmetallic mineral products and chemical products, the percentages are higher than 80 per cent. In all of the other sectors, the percentages are higher than 90 per cent. In general, the percentages are very high which suggests that there is effectively a positive correlation between offshoring and exports, as in all cases the proportion of the number of exporting firms is lower when offshoring does not take place. 


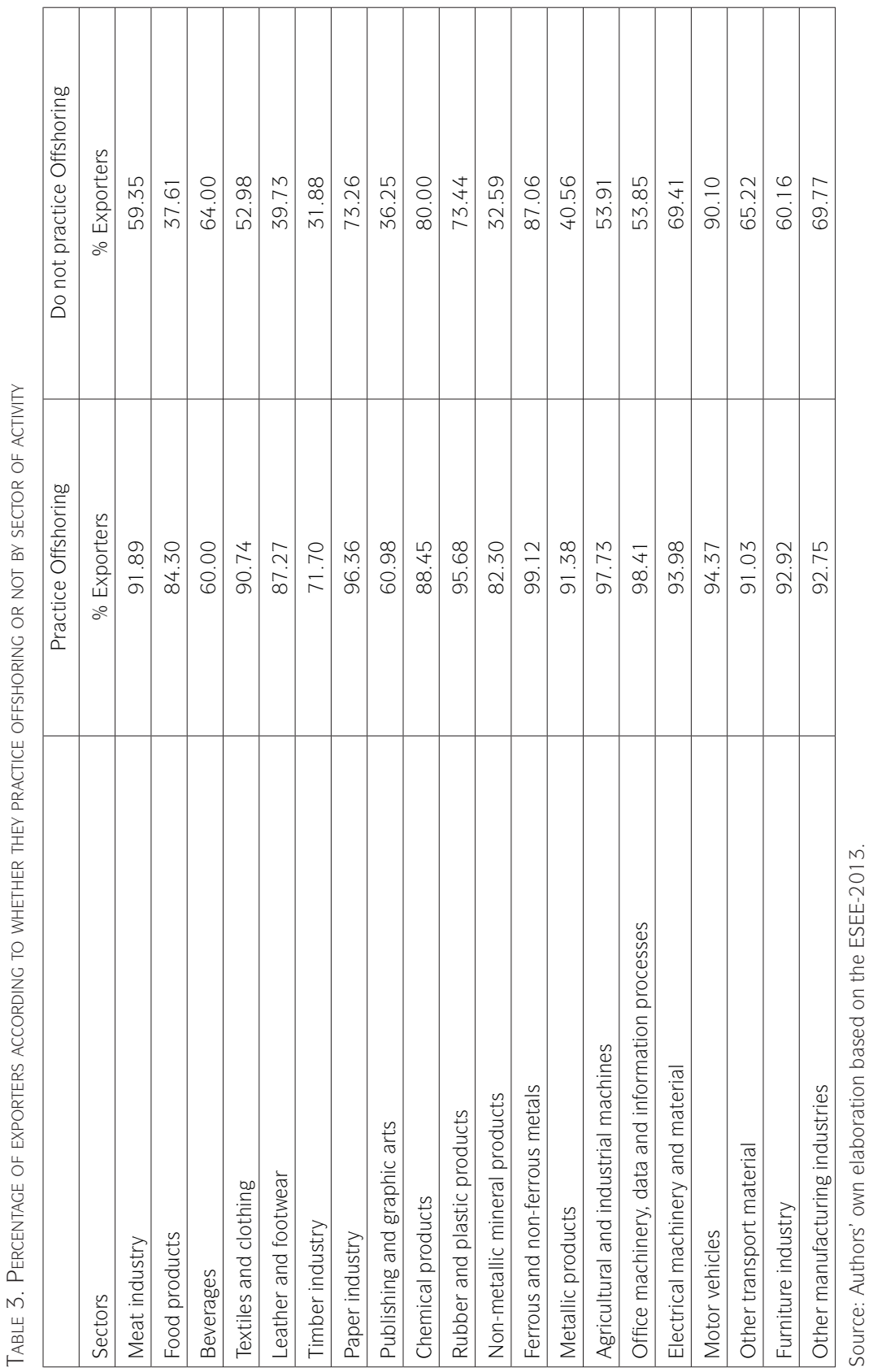




\section{EMPIRICAL ANALYSIS}

In order to analyse the relationship between offshoring and the exporting activity in greater depth, an econometric analysis has been conducted which considers the two elements. Based on the information provided by the Survey on Business Strategies (Encuesta de Estrategias Empresariales, ESEE) of 2013, two regression models have been used that link whether the firms' exports and the export intensity (exports in terms of total sales) with whether offshoring is practiced. Given the different exporting behaviour of the large and small firms, as the majority of the former export, the models have also been estimated for the two groups of firms according their size (larger/smaller than 200 employees which is the benchmark established in the database and used to develop different survey methodology in each group).

The literature has indicated many factors that affect the decision to export and the export intensity. The aim of this paper is not to determine the complete set of these elements but to simply control other variables that may be relevant in order to show the differential behaviour of the firms that practice offshoring from those that do not. Therefore, as control variables, the regression models include a variable referring to the size of the firm (measured by the number of employees), the differentiation of the technological product (through $R \& D$ costs in terms of sales) and a series of seven sectoral dummy variables (the food and beverages sector; the sector that comprehends textile products, clothing and footwear; the industry of paper, publishing, timber, furniture and other; the sector of chemical products, rubber, plastic and non-metallic minerals; the fifth dummy variable makes reference to all the metal-related manufacturing industries, including machinery; the industry of electrical equipment and electronics and finally a seventh dummy for the sector of vehicles and other transport material). The twenty sectors that the NACE Rev2 provides, were summarized in seven, since some of them had few observations with firms that offshore to run the analysis. In the econometric estimation the dummy variable that refers to the food and beverages sector is taken as base reference, which does not have any further implication.

The results of the logit model for the exporting activity are presented in Table 4. As well as the positive and significant values for the control variables, the table shows that the variable referring to whether the firm practices offshoring has a positive and statistically significant value which should be interpreted to mean that those firms that practice offshoring have a higher probability to export, once the rest of the factors have been controlled. This effect is equally important in large as well as in small firms.

In order to analyse the influence of the offshoring strategy on the probability of exporting in greater detail, the probability of exporting (for an average firm) has been computed both for a firm that offshores as for a firm that does not do it. The estimated probability that an average offshoring firm exports is 0.8513 while for a non-offshoring firm is 0.5917 (these values are 0.8016 and 0.5582 for the subset of small firms and 0.9578 and 0.8886 for large firms) 
which gives an idea on the importance that offshoring has to be present in international markets also as a seller.

A more detailed information on the importance of offshoring can be obtained on the basis of the estimated probabilities for an average firm for the different sizes of firms, according to whether offshoring is practiced or not. These values have been computed and displayed in Graph 1. They show that for small firms, the probability of exporting is notably higher among those that practice offshoring, although as the size of the firm increases this increase in probability is lower as the probability of larger firms to export is much higher, as reflected in many studies. Among the large firms, there is also a positive differential (and statistically significant given the result shown in Table 4), only lower due to the high percentage of firms that export.

TABLE 4: ESTIMATION OF LOGIT MODELS FOR EXPORTING

\begin{tabular}{|c|c|c|c|c|c|c|}
\hline & \multicolumn{2}{|c|}{ All the firms } & \multicolumn{2}{|c|}{ Small firms } & \multicolumn{2}{|c|}{ Large firms } \\
\hline \multirow[t]{2}{*}{ Constant } & -0.71623 & $* *$ & -1.20654 & $* *$ & 0.46274 & \\
\hline & $-(4.69)$ & & $-(6.78)$ & & (0.79) & \\
\hline \multirow[t]{2}{*}{ Practices offshoring } & 1.54152 & $* *$ & 1.35719 & $* *$ & 1.11492 & $* *$ \\
\hline & $(10.90)$ & & (8.89) & & (2.23) & \\
\hline \multirow[t]{2}{*}{$\mathrm{R} \& \mathrm{D} /$ Sales } & 0.17684 & $* *$ & 0.13294 & $* *$ & 0.1727 & \\
\hline & (2.95) & & (2.29) & & $(0.87)$ & \\
\hline \multirow[t]{2}{*}{ Number workers } & 0.00797 & $* *$ & 0.02184 & $* *$ & 0.00115 & \\
\hline & (7.78) & & (9.97) & & $(1.28)$ & \\
\hline \multirow[t]{2}{*}{ Textiles \& clothing } & 0.22348 & & 0.35973 & & -0.56511 & * \\
\hline & $(0.96)$ & & $(1.46)$ & & $-(0.47)$ & \\
\hline \multirow[t]{2}{*}{ Paper/Timber } & 0.12763 & & 0.22522 & & 1.41735 & \\
\hline & $(0.66)$ & & $(1.08)$ & & $(1.29)$ & \\
\hline \multirow[t]{2}{*}{ Chemical } & 0.53272 & $* *$ & 0.58031 & $* *$ & 1.06093 & * \\
\hline & $(2.58)$ & & $(2.57)$ & & $(1.50)$ & \\
\hline \multirow[t]{2}{*}{ Metals \& machinery } & 0.33758 & $*$ & 0.37861 & * & 1.60571 & * \\
\hline & $(1.78)$ & & $(1.83)$ & & $(1.96)$ & \\
\hline \multirow[t]{2}{*}{ Electric Materials } & 0.73831 & $* *$ & 0.80746 & $* *$ & 0.79849 & \\
\hline & $(2.09)$ & & $(2.12)$ & & $(0.70)$ & \\
\hline \multirow[t]{2}{*}{ Transport } & 0.28355 & & -0.00637 & & 1.88973 & $* *$ \\
\hline & $(0.80)$ & & $-(0.02)$ & & $(1.74)$ & \\
\hline Number observations & 1,672 & & 1,368 & & 304 & \\
\hline Log. Likelihood & -786.912 & & -681.168 & & -62.420 & \\
\hline LR lilelihood & 476.94 & $* *$ & 418.49 & $* *$ & 21.83 & $* *$ \\
\hline
\end{tabular}


GRAPH 1: ESTIMATED PROBABILITY OF EXPORTING ACCORDING TO WHETHER THEY PRACTICE OFFSHORING FOR DIFFERENT SIZES

SMALL FIRMS (200 OR LESS EMPLOYEES)

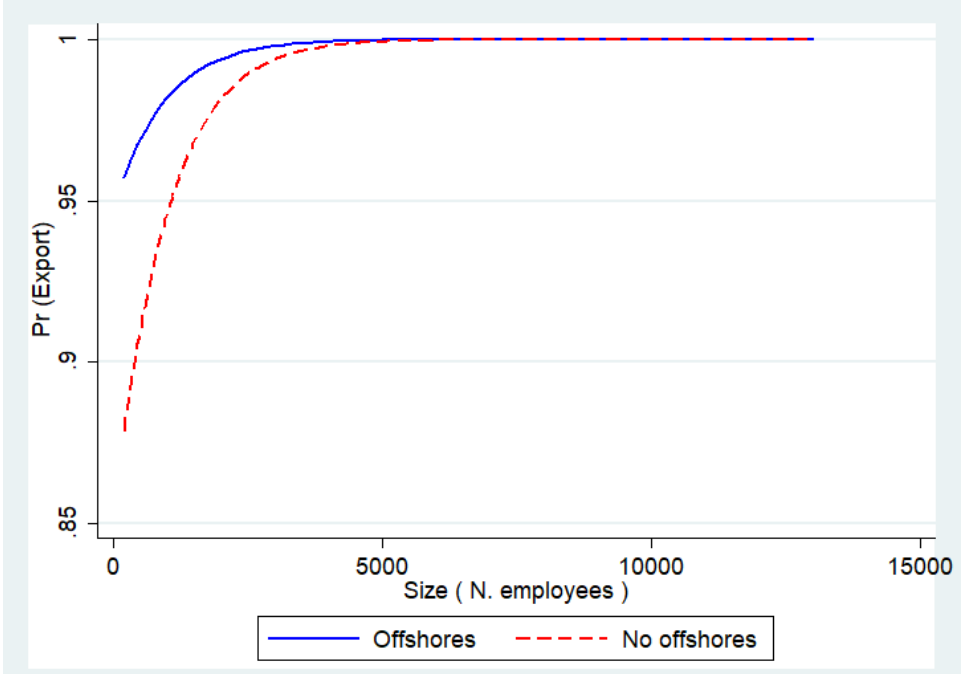

LARGE FIRMS (MORE THAN 200 EMPLOYEES)

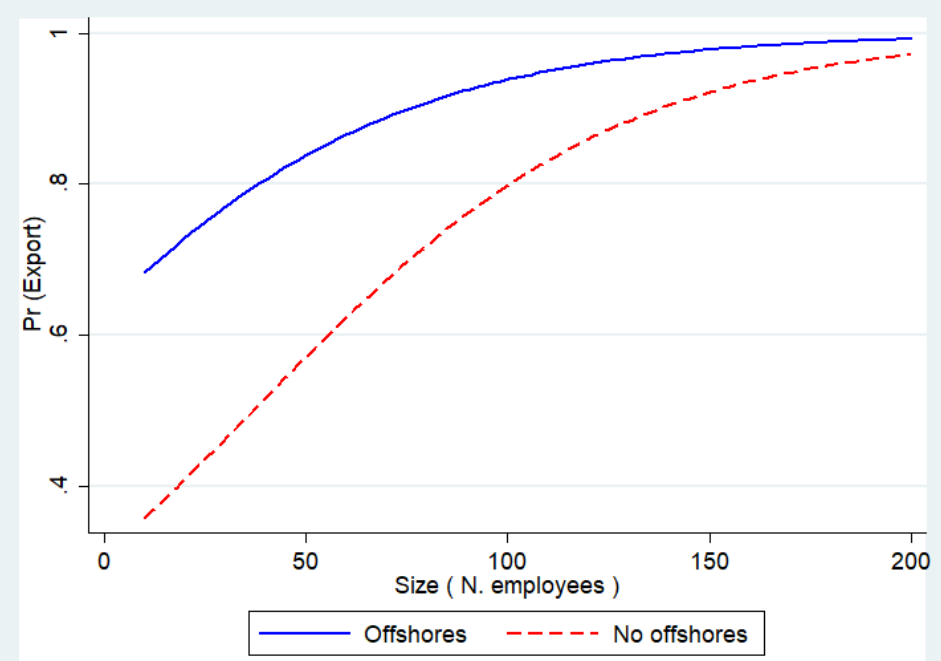




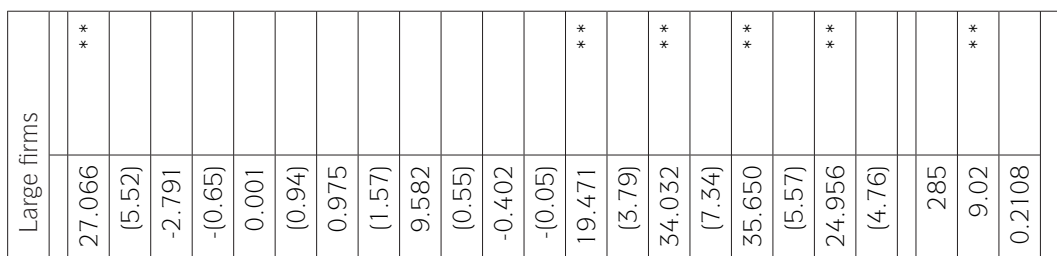

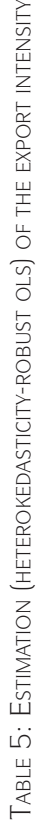

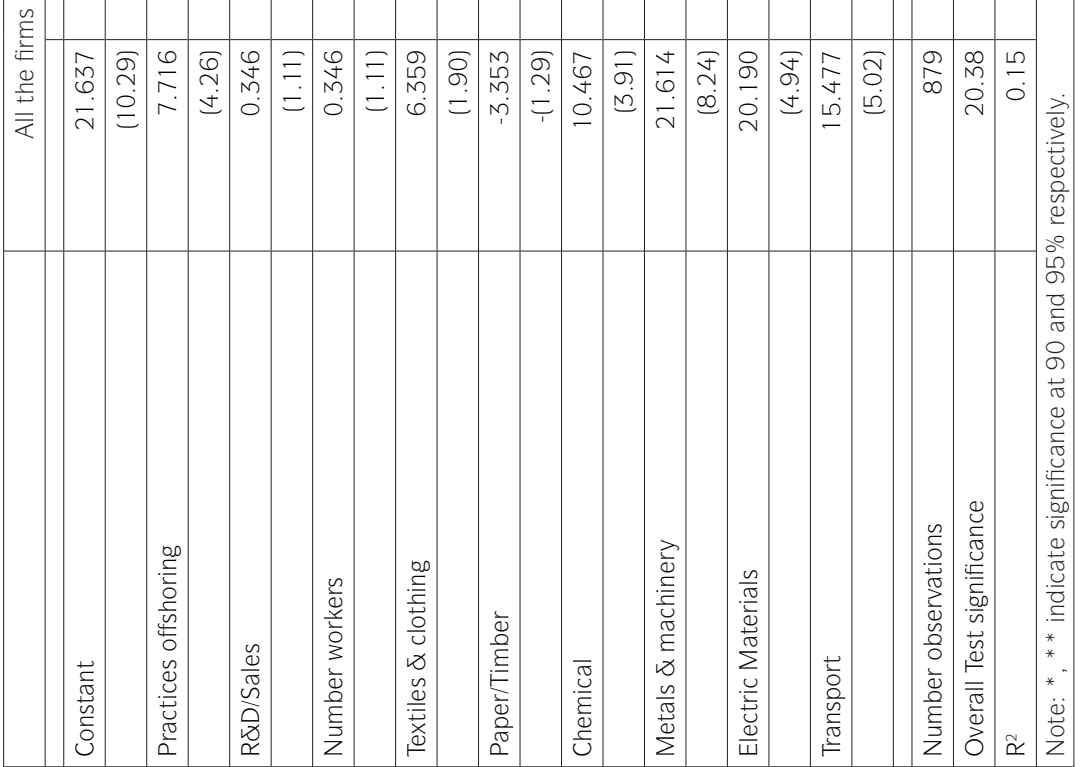


The econometric study is completed with the analysis of the influence of offshoring on the exporting intensity shown in Table 5. The table shows that the dummy variable referring to the offshoring strategy has a positive and statistically significant estimated value for the whole set of firms, which is due to small firms; for large firms, which have a greater propensity to export, the sign is not significative. In the case of firms with 200 workers or less, the estimated value is higher than seven percentage points; a noteworthy result that reveals the significant influence that foreign sourcing has on the ease with which output is sold in international markets. However, the improvement in competitiveness that this could represent for large firms is not relevant, as these firms find their international factors of competitiveness in other elements.

\section{ConCLUSIONS}

Offshoring is a strategy that aims to increase the productivity level of firms and different studies, both from a theoretical and empirical perspective have confirmed the positive effect that it has. This paper contributes to the literature on the consequences of offshoring, focused on the export behaviour of those firms according to their offshoring strategy. This topic has been identified in the literature as one that needs a further development and where additional research is needed. Offshoring, at the extent that increases firms' productivity as well as provides a better knowledge of foreign markets, may become a factor that promotes exports for firms that implement it. So, it may affect the firm's activity (beyond their supply mode) with relevant consequences for the economy.

The paper presents an analysis of the exporting activities of Spanish manufacturing firms according to their sourcing (offshoring or not) mode, particularly on the probability of being an exporter (extensive margin) and on the export intensity (intensive margin) based on firm data. The data source used is the Survey on Business Strategies (Encuesta de Estrategias Empresariales, ESEE) carried out by the SEPI Foundation of Spain's Ministry of Industry for the year 2013 which contains information about approximately 2,000 firms. The analysis has been carried out for the total number of firms in accordance with whether they practice offshoring or not, whether they carry it out between firms in the same group or with third parties.

In all cases, the results show that when offshoring is practiced, the number of exporting firms is much higher and also the export/sales ratio is larger, although this positive effect is considerably higher for cases of mediumsized firms and most of all of the small firms. The effect is also positive in the case of large firms but to a lesser extent. This result suggests that offshoring strategies are competitiveness' strategies that favour the exports of the firms and therefore their growth, particularly those ones with smaller size. This effect could compensate some of the possible negative effects of offshoring that has been sometimes questioned given its negative impact on employment in the short term. 
As previously discussed, the impact of offshoring on exports may be due to causes derived from price competitiveness (acquisition of inputs at a lower price abroad than in the domestic country) or to factors related to technology (increase in productivity derived from an increase in imports of a greater variety of inputs or with superior technology incorporated into them, and an improvement in the production processes due to the complementarity of the new imported inputs with the domestic inputs).

An issue yet to be analysed is the identification of the nature of the effects that offshoring has on Spanish manufacturing firms. This requires a consideration of the offshoring data, distinguishing the countries of origin of the imports in order to determine whether the effect is produced by the import of inputs from countries with lower costs than Spain, by the import of inputs from more advanced countries, or whether the effect is produced in both cases.

\section{REFERENCES}

Agnese, P. (2012): "Employment Effects of Offshoring across Sectors and Occupations in Japan", Asian Economic Journal, 26(4), 289-311.

Amiti, M. and Davis, D. (2011): "Trade, Firms and Wages: Theory and Evidence", Review of Economic Studies, 79(1), 1-36.

Amiti, M. and Wei, S.J. (2009): "Service Offshoring and Productivity: Evidence from the United States", The World Economy, 32(2), 203-220.

Aristei, D., Castellani, D. and Franco, C. (2013): "Firms' Exporting Activities: Is There a Two-Way Relationship?", Review of World Economics, 149(1), 55-84.

Awe, O.A., Kulangara, N. and Henderson, D.F. (2018): "Outsourcing and Firm Performance: A Meta-Analysis", Journal of Strategy and Management, $11(3), 371-386$.

Bas, M. and Strauss-Kahn, V. (2014): "Does Importing more Inputs raise Exports? Firm Level Evidence from France", Review of World Economics, 150(2), 241-275.

Bertrand, O. (2011): "What Goes around, Comes around: Effects of Offshore Outsourcing on the Export Performance of Firms", Journal of International Business Studies, 42, 334-344.

Blinder, A. S. (2006): "Offshoring: The Next Industrial Revolution?", Foreign Affairs, 85(82), 113-127.

Bogliacino, F., Guarascio, D. and Cirillo, V. (2018): "The Dynamics of Profits and Wages: Technology, Offshoring and Demand", Industry and Innovation, 25(8), 778-808.

Cadarso, M.A., Gómez, N., López, L. A. and Tobarra, M.A. (2008): “The EU Enlargement and the Impact of Outsourcing on Industrial Employment in Spain, 1993-2003", Structural Change and Economic Dynamics, 19, 95108 . 
Campa, J.M. and Goldberg, L. (1997): "The Evolving External Orientation of Manufacturing: A Profile of Four Countries”, Fed. Reserve Bank New York Economic Policy Review, 3, 53-81.

Choquette, E. (2019): “Import-Based Market Experience and Firms' Exit from Export Markets”, Journal of International Business Studies, 50(3), 423449.

Crinō, R. (2010): "Employment Effects of Service Offshoring: Evidence from Matched Firms", Economic Letters, 107, 253-256.

Danninger, S. and Joutz, F. (2008): "What Explains Germany's Rebounding Export Market Share?”, CESifo Economic Studies, 54(4), 681-714.

Ethier, W. (1982): "National and International Returns to Scale in the Modern Theory of International Trade", American Economic Review, 72(3), 389405.

Fariñas, J.C. and Martín, A. (2009): "Innovaciones organizativas y productividad: el caso del outsourcing internacional", Investigaciones Regionales. Monográfico. 251-275.

Feenstra, R. (1998): "Integration of Trade and Disintegration of Production in the Global Economy”, Journal Economic Perspectives, 12, 31-50.

Feenstra, R. and Hanson, G. (1996): "Globalization, Outsourcing and Wage Inequality”, American Economic Review, Papers and Proceedings 86, 24045.

Gandoy, R., Díaz Mora, C. and Córcoles, D. (2014): "La inserción en redes de produccioon como vía de internacionalización para las Pymes más capaces”, Información Comercial Española, 877, 131-149.

Gorg, H. and Hanley, A. (2005): "Labour Demand Effects of International Outsourcing: Evidence from Plant-level Data", International Review of Economics and Finance, 14(3), 365-376.

Grossman, G., and Helpman, E. (1991): Innovation and Growth in the Global Economy. MIT Press, Cambridge, MA (United States).

Grossman, G. M. and Rossi-Hansberg, E. (2006): "The Rise of Offshoring: It's Not Wine for Cloth Anymore”. Symposium The New Economic Geography: Effects and Policy Implications.

Helpman, E. (2011): Understanding Global Trade. Harvard University Press. United States.

Hernāndez, V. and Nieto, M.J. (2018): "Inward-outward Connections and their Impact on Firm Growth", International Business Review, 25(1), 296-306.

Hijzen, A., Pisu, M., Upward, R. and Wright, P. (2015): "Employment, Job Turnover and Trade in Producer Services: UK Firm-Level Evidence", Canadian Journal of Economics, 44(3), 1020-1043.

Hummels, D., Jorgensen, R., Munch, J., and Xiang, C. (2014): “The Wage Effects of Offshoring: Evidence from Danish Matched Worker-firm Data”, American Economic Review, 104(6), 1597-1629.

Hummels, D., Ishii, J. and Kei-Mu Y. (2001): "The Nature and Growth of Vertical Specialization in Word Trade”, Journal International Economics, 54, 75-96. 
Kasahara, H. and Lapham, B. (2013): "Productivity and Decision to Import and Export: Theory and Evidence”, Journal of International Economics, 89(2), 297-316.

Kleinert, J., and Zorell, N. (2012): "The Export Magnification Effects of Offshoring”. European Central Bank - Working Papers Series, 1430.

Krishna, P., Poole, J.P. and Senses, M.Z. (2011): "Wage Effects of Trade Reform with Endogenous Worker Mobility”, NBER Working Paper, 17256.

Lahiri, S. (2016): "Does Outsourcing Really Improve Firm Performance? Empirical Evidence and Research Agenda", International Journal of Management Reviews, 18, 464-497.

Liu, R. and Trefler, D. (2008): "Much Ado About Nothing: American Jobs and the Rise of Service Outsourcing to China and India", NBER Working Paper 14061 .

Lo Turco, A.; Maggioni, D. (2013): "On the Role of Imports in Enhancing Manufacturing Exports”, The World Economy, 36(1), 93-120.

Markusen, J. (1989): "Trade in Producer Services and in Other Specialized Intermediate Inputs", American Economic Review, 79(1), 85-95.

Martins, P. and Opromolla, L.D. (2009): "Exports, Imports and Wages: Evidence from Matched Firm-Worker-Product Panels". IZA discussion paper 4646.

Melitz, M.J. (2003): "The Impact of Trade on Intra-industry Reallocations and Aggregate Industry Productivity”, Econometrica, 71, 1695-1725.

Michel, B. and Rycx, F. (2012): "Does Offshoring of Materials and Business Services Affect Employment? Evidence from a Small Open Economy", Applied Economics, 44, 229-251.

Muûls, M. and Pisu, M. (2009): "Imports and Exports at the Level of the Firm: Evidence from Belgium”, The World Economy, 32(5), 692-734.

Myro, R. (2015): España en la economía global. Claves del éxito de las exportaciones españolas. RBA Libros, S.A., Madrid

Myro, R. (dir.), Álvarez López, M; Fernández-Otheo, C.M.; Rodríguez Rodríguez, D. and Vega Crespo, J. (2013): Fortalezas competitivas y sectores clave en la exportación Española, Instituto de estudios Económicos (Colecciōn Estudios), Madrid.

Olsen, K.B. (2006): "Productivity Impacts of Offshoring and Outsourcing: A review", OECD Science, Technology and Industry Working Papers, 2006/1, OECD Publishing.

Tate, W. (2014): "Offshoring and Reshoring: U.S. Insights and Research Challenges", Journal of Purchasing and Supply Chain Management, 20(1), 66-68.

Winkler, D. (2010): "Services Offshoring and its Impact on Productivity and Employment: Evidence from Germany, 1995-2006”, The World Economy, 33(12), 1672-1701. 
